University of Nebraska - Lincoln

DigitalCommons@University of Nebraska - Lincoln

Publications, Agencies and Staff of the U.S.

Department of Commerce

U.S. Department of Commerce

6-16-2005

\title{
Japan's whaling plan under scrutiny
}

Nicholas J. Gales

Toshio Kasuya

Phillip J. Clapham

Robert L. Brownell Jr.

NOAA, rlbcetacea@aol.com

Follow this and additional works at: https://digitalcommons.unl.edu/usdeptcommercepub

Part of the Environmental Sciences Commons

Gales, Nicholas J.; Kasuya, Toshio; Clapham, Phillip J.; and Brownell, Robert L. Jr., "Japan's whaling plan under scrutiny" (2005). Publications, Agencies and Staff of the U.S. Department of Commerce. 119. https://digitalcommons.unl.edu/usdeptcommercepub/119

This Article is brought to you for free and open access by the U.S. Department of Commerce at DigitalCommons@University of Nebraska - Lincoln. It has been accepted for inclusion in Publications, Agencies and Staff of the U.S. Department of Commerce by an authorized administrator of DigitalCommons@University of Nebraska - Lincoln. 


\section{COMMENTARY}

\section{Japan's whaling plan under scrutiny}

Useful science or unregulated commercial whaling? Nicholas J. Gales, Toshio Kasuya, Phillip J. Clapham and

Robert L. Brownell Jr consider the scientific merits of Japan's whaling activities.

E

ighteen years after initiating scientific whaling in Antarctic waters, Japan - presented a new and more ambitious programme to the International Whaling Commission (IWC); the proposal was made in early June during the IWC's annual meeting in Ulsan, Korea. Japan now wishes to more than double its annual catch of Antarctic minke whales (from about 440 to 935), and to expand lethal sampling to include an additional yearly take of 50 humpback and 50 fin whales. Unlike catches for commercial whaling, scientific catches are unregulated. Since 1987, Japan has taken some 6,800 minke whales from Antarctic waters, despite ongoing criticism of the relevance and direction of Japan's research.

The IWC was set up to regulate commercial whaling and to conserve whale populations, under the authority of the 1946 International Convention for the Regulation of Whaling. Following a well-documented failure of management that led to the collapse of most global whale populations, the IWC set a zero quota for commercial whaling (the moratorium). This was made effective from 1986. Norway, the former Soviet Union and Japan initially objected to the moratorium, but Japan withdrew its objection and ceased commercial whaling in 1988.

Scientific whaling occurs under Article VIII of the convention, whereby each member nation can grant its nationals a permit to take whales for scientific purposes. Unlike the international regulations on commercial and aboriginal/subsistence whaling, the objectives of the research and the number of whales to be killed for scientific purposes are set unilaterally by the member nation. Although the Scientific Committee (SC) of the IWC provides expert assessment of national research plans, the nations carrying out scientific whaling are not obliged to modify their research.

The first phase of Japan's scientific whaling commenced in the 1987-88 Antarctic season. In 1994, Japan also began scientific whaling operations in the western North Pacific, originally targeting minke whales, but subsequently expanding its catches to include Bryde's whales, sei whales and sperm whales. Since 1987, Japan has taken approximately 7,900 minke whales, 243 Bryde's whales, 140 sei whales and 38 sperm whales for scientific purposes. By contrast, 840 whales were killed globally by Japan

\section{IMAGE UNAVAILABLE FOR COPYRIGHT REASONS}

Since 1987, Japan has taken around 8,300 whales, including 38 sperm whales, for scientific purposes.

for scientific research between 1954 and the moratorium. Together, all other nations have killed about 2,100 whales for scientific research since 1952. Japan's expanded programme will result in annual catches that are more than half the total cumulative catches for scientific research by all nations in the past half-century. Such takes differ little in scale from commercial whaling, and must be justified by an adequate scientific rationale.

\section{Conflicting opinion}

The lethal sampling of whales for scientific research is extremely controversial ${ }^{1-4}$. Many SC members (ourselves included) have consistently complained that such catches do not have sufficient scientific basis. The strongest scientific argument in favour of lethal sampling - the collection of genetic samples for determining population structure could be conducted far more efficiently using non-lethal biopsy techniques. At the IWC meeting this month, a paper signed by 63 scientists representing 16 out of 30 national delegations contested the scientific claims of the Japanese proposal.

The tragedy for the scientists involved in the debate on scientific whaling is that they are labelled as either pro- or anti-whalers. This impugns objectivity and relegates any discussion to polarized politics. As long as the whale catches remained small, the consequences of this gridlock were limited to political frustration. But with Japan's proposed escalation in the number of species and individual whales to be sampled, and without any regulatory process to manage these catches, the consequences for whale populations may well be more serious.

A 1997 IWC review of Japan's scientific whaling reported that the research conducted failed to meet its stated objectives and that the data derived were "not required for management". Even today, the programme's publication record is very poor for an 18-year research endeavour of this size. Very few peer-reviewed papers have come from the Japanese programme, none has been published in the IWC's management-focused Journal of Cetacean Research and Management, and only one (on stock structure) is relevant to the scientific parameters used for species management.

A further criticism by SC members is that Japan's scientific whaling occurs within the IWC's Southern Ocean Whale Sanctuary where commercial whaling was specifically prohibited (so that scientists could study 
populations not subject to whaling). However, repeated calls by the IWC to Japan to halt its scientific whaling activities have had no effect.

At this year's IWC meeting, SC members were asked to provide an objective scientific assessment of Japan's new whaling proposal. This was to be done without the benefit of an independent review of Japan's previous 18 years of Antarctic scientific whaling, and with the knowledge that there is no mechanism in the convention to ensure that Japan responds to any review process.

\section{Looking back}

Japan intends to proceed with its expanded whaling programme before an independent review is completed (scheduled for late 2006). So it is important to examine how this second phase of whaling differs from the first 18-year phase, and how realistic or relevant Japan's new objectives are. Although there is no time limit to this second phase, in an equivalent 18 -year period Japan can be expected to take about 17,000 minke whales, 820 fin whales and 800 humpback whales from the Southern Ocean. This will be in addition to increased catches in the western North Pacific.

During its first 18-year phase of whaling, Japan's main scientific objective in the Antarctic was to improve estimates of minke whale population parameters (such as age-specific mortality rates), which, Japanese scientists argued, were needed for effective management of the whales. Yet previous IWC management failures have been attributed to problems with such data $^{3}$, and procedures no longer require it. Despite this, Japan continues to include this objective in its plans. A notable addition to Japan's aims is to manipulate the ecosystem through selective culling of certain species, with the explicit intention of reducing interspecific competition and thus promoting population growth in the most economically valuable species (such as blue whales).

At the heart of Japan's new proposal is their hypothesis that whales are competing directly for a limited resource (krill). Ignoring the fact that current whale populations, and thus their collective consumption of prey, remain at fractions of pre-whaling levels, Japan postulates that the recovery of depleted blue whales will be negatively affected by population increases of humpback, fin and minke whales (although data on abundance and population trends for all species are highly uncertain or non-existent). This hypothesis has been proposed using primarily unreviewed and unpublished data collected during the first 18-year phase of scientific whaling. Moreover, Japan proposes using a crude ecosystem approach to examine this hypothesis. This includes constructing simplistic models of competition among whale species, and inadequately measuring

\section{IMAGE UNAVAILABLE FOR COPYRIGHT REASONS}

\section{Strong opposition: demonstrators in South Korea object to Japan's new whaling proposal.}

other components of the Southern Ocean ecosystem including krill abundance and habitat features.

A better understanding of the Southern Ocean ecosystem is critical to considerations far beyond the management of whales. Oceanography, and studies addressing climate change and fishery management have led to a series of successful multi-disciplinary, multinational collaborations. The Convention on the Conservation of Antarctic Marine Living Resources (CCAMLR), to which Japan is a signatory, applies an ecosystem approach to the conservation and rational use of the Southern Ocean's living resources (primarily krill and fish). To this end, CCAMLR's members have a strong history of ecosystem research, and of developing ecosystem models. Studying the biomass and dynamics of krill and krill predator populations (including whales, the data on which come from the IWC) are within the mandate of CCAMLR. In contrast, Japan's proposal to unilaterally conduct its whale-focused ecosystem-scale research, isolate it from the benefits of multi-disciplinary scientific input and collaboration.

From a conservation perspective, Japan's planned catches of humpback and fin whales in the Southern Ocean are particularly worrying. Humpback whales are listed internationally as vulnerable and fin whales as endangered heavy exploitation in the twentieth century saw total Southern Hemisphere catches of 723,000 fin whales and 197,000 humpbacks. The species have been protected from any form of legal whaling in this hemisphere since 1966 (humpbacks) and 1985 (fin whales).

Very little is known about the status of fin whales in the Southern Ocean. But some of the humpback whales feeding where Japan intends to conduct whaling come from small, highly depleted populations that breed in the tropical South Pacific. Because gunners on catcher boats cannot know the population from which a particular whale is taken, catches in these regions could have disastrous effects in terms of stock recovery for these populations.

\section{Up for review}

It is time for the IWC to review the provisions of the International Convention under which scientific whaling permits are issued. Science is stipulated as the basis of management procedures within the IWC. But the lack of a science-based regulatory process to manage scientific whaling, and the escalation of this whaling to commercial scales on the basis of poorly established and controversial scientific claims, challenge the idea that the IWC can deliver a robust framework for whale conservation or a sustainable whaling industry.

The SC must be given a real role in determining the IWC's scientific needs, the best methods to achieve these needs, and what risks such research might pose to the conservation of whale populations. The minimum regulations applied to any proposed lethal catches made for scientific purposes, should they be accepted by the SC, must equal those applied to commercial whaling. Furthermore, if commercial whaling resumes, any lethal catches must be part of future national quotas.

Japan's scientific whaling programme yields considerable annual revenue from the commercial sale of whale meat, estimated at US $\$ 50$ million earlier this decade; this will rise considerably as catches increase. The Japanese government provides annual subsidies of some further US $\$ 10$ million for cetacean research. These revenues are invested in the maintenance and operation of the catcher/processor vessels in addition to the Japanese Institute of Cetacean Research that conducts the science associated with scientific whaling. The risk for Japan is that dependence upon these revenues could drive its quotas for scientific whaling, yet leave the real scientific questions unaddressed.

Nicholas J. Gales is at the Australian Antarctic Division, Channel Highway, Kingston 7050,

Tasmania, Australia.

Toshio Kasuya is at the Teikyo University of Science and Technology, Uenohara, Yamanashi 409-0193, Japan.

Phillip J. Clapham is at the Alaska Fisheries Science Center, National Marine Mammal Laboratory, 7600 Sand Point Way NE, Seattle, Washington 98115, USA.

Robert L. Brownell Jr is at the Southwest Fisheries Science Center, 1352 Lighthouse Avenue Pacific Grove, California 93950, USA.

1. Brownell, R. L., Tillman, M. F., Notarbartolo di Sciara, G. Berggren, P., \& Read, A. J. Science 290, 1696 (2000).

2. Nagasaki, F. Nature 344, 189-190 (1990).

3. de la Mare, W. K. Nature 345, 771 (1990).

4. Normile, D. Science 289, 2264-2265 (2000). 